\title{
Effects of vocal aerobic treatment on voice improvement in patients with voice disorders*
}

\author{
Jun-Hee Park ${ }^{1}$ Jae-Yeon Yoo $^{2} \cdot$ Ha-Na Lee ${ }^{3, * *}$ \\ ${ }^{I}$ Department of Otolaryngology-Head and Neck Surgery, Chosun University School of Medicine, Gwangju, Korea \\ ${ }^{2}$ Department of Speech Language Pathology, Honam Univerisity, Gwangju, Korea \\ ${ }^{3}$ Department of Otolaryngology, Chosun University Hospital, Gwangju, Korea
}

\begin{abstract}
This study aimed to investigate the effects of vocal aerobic treatment (VAT) on the improvement of voice in patients with voice disorders. Twenty patients (13 males, 7 females) were diagnosed with voice disorders on the basis of videostroboscopy and voice evaluations. Acoustic evaluation was performed with the Multidimensional voice program (MDVP) and Voice Range Profile (VRP) of Computerized Speech Lab (CSL), and aerodynamic evaluation with PAS (Phonatory Aerodynamic System). The changes in F0, Jitter, Shimmer, and NHR before and after treatment were measured by MDVP. F0 range and Energy range were measured with VRP before and after treatment, and the changes in Expiratory Volume (FVC), Phonation Time (PHOT), Mean Expiratory Airflow (MEAF), Mean Peak Air Pressure (MPAP), and Aerodynamic Efficiency (AEFF) with PAS. Videostroboscopy was performed to evaluate the regularity, symmetry, mucosal wave, and amplitude changes of both vocal cords before and after treatment. Voice therapy was performed once a week for each patient using the VAT program in a holistic voice therapy approach. The average number of treatments per patient was 6.5. In the MDVP, Jitter, Shimmer, and NHR showed statistically significant decreases $(p<.001, p<.01, p<$ $.05)$. VRP results showed that $\mathrm{Hz}$ and semitones in the frequency range improved significantly after treatment $(p<.01, p<$ $.05)$, as did PAS, FVC, and PHOT $(p<.01, p<.001)$. The results for videostroboscopy, functional voice disorder, laryngopharyngeal reflux, and benign vocal fold lesions were normal. Thus, the VAT program was found to be effective in improving the acoustic and aerodynamic aspects of the voice of patients with voice disorders. In future studies, the effect of VAT on the same group of voice disorders should be studied. It is also necessary to investigate subjective voice improvement and objective voice improvement. Furthermore, it is necessary to examine the effects of VAT in professional voice users.
\end{abstract}

Keywords: vocal aerobic treatment, voice therapy, voice disorder

\footnotetext{
* This work was supported by Research Foundation of Chosun University in 2016.

**hhln34@gmail.com, Corresponding author

Received 1 August 2019; Revised 26 August 2019; Accepted 9 September 2019

(c) Copyright 2019 Korean Society of Speech Sciences. This is an Open-Access article distributed under the terms of the Creative Commons Attribution NonCommercial License (http://creativecommons.org/licenses/by-nc/4.0) which permits unrestricted non-commercial use, distribution, and reproduction in any medium, provided the original work is properly cited.
} 
과 같은 잘못된 음성산출 습관으로 인해 음성의 변화가 나타나 는 장애이다. 음성장애는 원인에 따라 기능적 음성장애, 기질적 음성장애, 신경학적 음성장애로 분류된다(Boone et al., 2014). 기능적 음성장애 환자의 경우 음성치료를 통해 환자의 발성습 관을 확인하고 이를 변화시켜 올바른 음성을 산출할 수 있도록 돕는다. 같은 음성장애 환자라도 나타나는 음성 특징과 성대의 움직임 양상이 다르기 때문에 환자 유형에 적절한 음성 치료 방 법을 적용하는 것이 중요하다.

음성치료 방법으로는 크게 음성촉진기법과 총체적 음성치료 로 나눌 수 있다. 음성촉진기법은 음성 증상에 따라 환자의 최 적 음성을 촉진시키는 것으로 25가지 음성촉진기법이 있다 (Boone et al., 2014). 총체적 음성치료는 음성산출에 필요한 호 흡, 발성, 공명 등의 과정을 하나의 과정으로 치료하는 것으로 성대기능훈련(vocal function exercise), 액센트기법(accent method), 반폐쇄성도훈련(semi-occluded vocal tract exercise, SOVT), 리실 버만 음성치료(Lee Silverman voice treatment, LSVT) 등이 있으 며 국내외 선행연구들을 통해 치료법의 효과가 보고되고 있다 (Kapsner-Smith, et al., 2015; Nasser Kotby, 1995; Ramig et al., 1995; Stemple et al., 1994; Verdolini Abbott, 2014). 또한 국내 연 구에서도 성대결절 환자를 대상으로 성대기능훈련을 실시한 연구, 노인 음성장애 환자를 대상으로 한 후두보정기법의 효과 를 알아본 연구, 성대결절 환자를 대상으로 액센트 치료법을 실 시한 연구, 과기능적 음성장애 환자에게 반폐쇄성도훈련을 실 시한 연구, 연축성 발성장애 환자에게 Lax Vox를 실시한 연구 등 많은 연구에서 총체적 음성치료를 실시한 후 음향학적·공기 역학적·청지각적 음성평가에서 유의미한 음성 개선을 보고하 였다(Kim, 2015; Kim et al., 2017; Kwon et al., 2001; Lim et al., 2009; Lim et al., 2016).

이처럼 임상에서 다양한 음성장애 환자 유형, 음성치료방법 효과에 대해 보고되어지고 있었다. 전통적으로 사용하고 있는 음성치료는 발성단계에서 음도훈련, 강세훈련, 공명훈련 등 음 성의 한 가지 특성을 활용하여 올바른 발성산출에 초점을 맞추 어 치료를 실시하였다. 그러나 음성은 음도, 강도, 공명 등 여러 가지 특성이 종합적으로 구성되어 있는 것으로 각각의 특성에 대해 단계적으로 중재할 필요가 있다. 기존 음성치료의 경우, 음성위생법, 후두 및 목 근육의 이완, 호흡방법에 대한 교육, 올 바른 발성산출훈련, 발성방법을 일반생활에서도 적용할 수 있 도록 중재하는 발화단계까지 이를 통합하여 하나의 프로그램 화된 치료법이 부족하였다. 따라서 환자가 음성산출과정을 쉽 게 이해할 수 있도록 단계적으로 구분하여 호흡, 발성, 발화 훈 련을 프로그램화하여 실시하는 것이 필요하다.

성대에어로빅치료 프로그램은 총체적 기법의 일환으로 Yoo \& Lee(2018)의 연구에서 소프라노 성악가를 대상으로 개발된 기법으로 이완, 호흡, 발성, 발화 단계로 구성되어 있으며 음성 산출 전반의 과정을 단계별 프로그램으로 중재하는 치료법이 다. 선행 연구에서 다양한 유형의 음성장애 환자를 대상으로 성 대에어로빅 치료 프로그램의 효과가 보고되고 있었다. 소프라 노 성악가를 대상으로 실시한 결과, 소프라노에 적절한 음도,
음역 개선, 주관적 음성 만족도 증가에 효과가 있다고 보고되었 고(Yoo \& Lee, 2018), 과기능적 음성장애 환자에서는 음도 상승, 음역대 증가, 음질 개선, 호흡능력 향상, 주관적 음성 만족도 증 가가 나타났다고 보고되었다(Kang \& Yoo, 2019).

그러나 성대에어로빅 치료 프로그램을 적용한 선행연구에서 는 연구 대상이 적어 성대에어로빅 치료 프로그램의 유용성을 밝히는 데 한계가 있었다.

이에 본 연구에서는 다양한 음성장애 환자 집단을 대상으로 성대에어로빅치료 프로그램의 유용성에 대해 알아보고자 하였 다. 연구 문제는 다음과 같았다.

첫째, 성대에어로빅치료 프로그램은 음성장애 환자의 음향 학적 매개변수(Fo, Jitter, Shimmer, NHR, Fo range, Energy range) 변화에 영향을 주는가?

둘째, 성대에어로빅치료 프로그램은 음성장애 환자의 공기 역학적 평가 매개변수(expiratory volume, FVC; phonation time, PHOT; mean expiratory airflow, MEAF; mean peak air pressure, MPAP; aerodynamic efficiency, AEFF) 변화에 영향을 주는 가?

셋째, 성대에어로빅치료 프로그램은 음성장애 환자의 후두 스트로보스코피에서 성대 소견(진폭, 점막파동, 양측성대의 대 칭성, 양측성대의 규칙성) 변화에 영향을 주는가?

\section{2. 연구방법}

\section{1. 연구대상 및 절차}

본 연구는 2018년 5월부터 2019년 2월까지 광주 소재 $\bigcirc \bigcirc$ 대 학교병원 이비인후과에 내원한 환자 중 후두내시경검사, 음성 검사 상 음성장애로 진단된 20명(남 13명, 여 7명)을 대상으로 실시하였다. 음성치료는 주 1 회 실시하였으며 치료 횟수는 311 회로 평균 6.5 회였다. 연구대상의 평균 연령은 45.7세였으며 연구대상자의 일반적인 특성은 표 1 과 같았다.

연구 절차는 치료 전 사전 평가 단계, 사후 평가로 진행되었 다. 사전 평가에서는 후두스트로보스코피, 음향학적 평가, 공기 역학적 평가를 실시하였다. 사후 평가에서는 사전 평가와 동일 한 평가를 실시하였으며 음성 치료 종결 2주 후 평가하였다. 
표 1. 연구대상자 정보

Table 1. Information of subject

\begin{tabular}{|c|c|c|c|}
\hline Diagnosis & Gender & Age & Session \\
\hline \multirow{9}{*}{$\begin{array}{l}\text { Benign vocal fold lesions } \\
\qquad(\mathrm{N}=9)\end{array}$} & Female & 26 & 9 \\
\hline & Female & 46 & 5 \\
\hline & Female & 49 & 5 \\
\hline & Female & 37 & 4 \\
\hline & Female & 39 & 4 \\
\hline & Female & 20 & 4 \\
\hline & Male & 57 & 4 \\
\hline & Male & 60 & 4 \\
\hline & Male & 44 & 7 \\
\hline \multirow{5}{*}{$\begin{array}{l}\text { Functional voice disorder } \\
\qquad(\mathrm{N}=5)\end{array}$} & Male & 56 & 4 \\
\hline & Male & 58 & 11 \\
\hline & Male & 56 & 8 \\
\hline & Male & 22 & 8 \\
\hline & Male & 29 & 6 \\
\hline \multirow{2}{*}{$\begin{array}{l}\text { Presbyphonia } \\
(\mathrm{N}=2)\end{array}$} & Male & 60 & 7 \\
\hline & Male & 74 & 10 \\
\hline $\begin{array}{l}\text { Vocal palsy } \\
\qquad(\mathrm{N}=1)\end{array}$ & Male & 68 & 11 \\
\hline $\begin{array}{l}\text { Incomplete glottal closure } \\
\qquad(\mathrm{N}=1)\end{array}$ & Female & 28 & 4 \\
\hline $\begin{array}{l}\text { Spasmodic dysphonia } \\
\qquad(\mathrm{N}=1)\end{array}$ & Male & 29 & 6 \\
\hline $\begin{array}{l}\text { Laryngopharyngeal reflux } \\
\qquad(\mathrm{N}=1)\end{array}$ & Male & 56 & 9 \\
\hline
\end{tabular}

\section{2. 평가도구}

\subsection{1. 음향학적 음성평가}

음향학적 평가는 치료 전·후 음성의 음질 및 음역의 향상 정 도를 확인하고자 실시하였다. 평가도구는 $\mathrm{CSL}$ (computerized speech lab, model 4150, KayPENTAX Elemetrics, Lincoln Park, NJ)의 MDVP(Multie-Dimensional Voice Program)와 VRP(Voice Range Profile)를 통해 실시하였다.

MDVP는 환자의 치료 전·후 음도 및 음질의 변화를 알아보고 자 실시하였다. 평가 시 마이크와 입이 $10 \mathrm{~cm}$ 떨어진 상태에서 녹음을 실시하였으며 환자에게 편안한 음도와 강도로 3 초간 모 음/ / / 를 연장 발성하도록 실시하였다. 음성분석은 가장 안정 적인 구간 1.5 초를 분석하였으며 기본주파수 $(\mathrm{Fo})$, 주파수변동 률(Jitter), 진폭변동률(Shimmer), 소음대배음비(NHR)를 측정하 였다.

$\mathrm{VRP}$ 는 환자의 치료 전·후 음역의 변화를 알아보고자 실시하 였다. 모음 $/ \mathrm{a} /$ 를 환자가 낼 수 있는 가장 낮은 음도에서 가장 높 은 음도까지 반음씩 발성하도록 하였다. 이후 반음씩 가장 낮은 강도에서 부터 가장 큰 강도까지 발성하여 측정하였다. 측정을 실시하기 전 언어재활사가 모델링을 제시하였다. 음성분석은 음도의 틈이 반음 3 개 이상인 경우 음도일탈(pitch break)로 간주 하여 제외한 후 주파수 범위(fo range), 강도범위(energy range)를 측정하였다.

\subsection{2. 공기역학적 음성평가}

공기역학적인 평가는 치료 전·후 환자의 발성과 관련된 호흡 기능을 알아보고자 PAS(Phonatory Aerodynamic System model
6600, Kay Pentax)를 사용하였다.

$\mathrm{PAS}$ 에서는 폐활량, 최대연장발성, 음성효율성 과제를 실시 하였다. 매개변수는 폐활량 $(\mathrm{FVC})$, 평균호기류율(MEAF), 최대 연장발성시간(PHOT), 평균성문하압(MPAP), 음성효율성(AEFF) 값을 측정하였다.

폐활량 과제는 환자가 PAS 검사 기기 내 포함된 마스크를 얼 굴에 밀착시킨 후 숨을 최대한 들이마시고 최대한 내밭도록 하 였다. 최대연장발성과제는 마스크를 얼굴에 밀착시킨 후 공기 를 최대한 들이마시고 편안한 음도와 강도로 모음/ / / 를 최대한 길게 연장 발성하도록 하였다. 폐활량과 최대연장발성과제는 3 회 실시하여 그 중 가장 길게 실시한 것을 분석하였다. 음성효 율과제는 마스크에 튜브를 고정시키고 얼굴에 밀착시킨 상태 에서 튜브는 입술과 윗니 사이에 고정시켜 실시하였다. 편안한 음도와 강도로 $/ \mathrm{pa} /$ 를 5 회 반복시킨 후 이를 분석하였다.

\subsection{3. 후두스트로보스코피 검사}

성대질환과 성 대 움직임 변화를 알아보고자 치료 전·후 환자 의 비디오스트로보스코피(videostroboscopy, model 9400, KayPentax Elemetrics Corp. NJ, USA)를 실시하였으며, 검사 결과의 판독 및 진단은 이비인후 두경부외과 전문의 1 명이 시행하였다.

\section{3. 성대에어로빅치료법}

음성치료는 성대에어로빅치료 프로그램을 실시하였다. 이 프로그램은 환자의 음성산출과정의 문제점을 확인하고 이를 효율적인 음성산출과정으로 변화시키는 데 목적이 있다. 나아 가 올바른 발성방법을 습득하고 이를 발화에서도 사용할 수 있 도록 일반화 시키는 데 초점을 둔 프로그램이다. 프로그램은 이 완단계, 호흡단계, 발성단계, 발화 단계 총 4단계로 구성되어 있 으며 각 단계의 수행도가 도달한 후 다음 단계를 실시하였다. 모든 단계에서는 환자의 수행도를 0 점부터 5 점까지 평가하였 으며, 4점이상일 경우 다음 단계를 실시하였다. 또한 호흡단계 와 발성단계에서는 최대호기시간, 최대연장발성시간이 15-20 초 이상인 경우 다음 단계를 진행하였다. 최대호기시간과 최대 연장발성시간의 경우 환자 수행도 및 음성장애 유형에 따라 차 등적용하여 다음 단계를 실시하였다.

치료의 시작은 상담과 음성위생법 교육을 통해 환자가 일상 생활에서 음성에 악영향을 미칠 수 있는 음성 오·남용 사례와 생활습관을 제거할 수 있도록 하였다. 이완단계는 신체 스트레 칭, 후두마사지를 통해 전반적인 신체의 긴장도를 완화시키는 활동을 실시하였다. 호흡단계는 복식호흡훈련, 호흡강세훈련 등을 통해 호흡 조절 능력을 향상시키는 활동을 실시하였다. 발 성단계는 기존에 습득하였던 복식호흡을 바탕으로 기본 발성 훈련, 다양한 음도에서 발성훈련, 강세훈련 등을 실시하여 환자 가 복식호흡방법을 발성에서도 지속하여 사용할 수 있도록 하 였다. 호흡과 발성 훈련은 자음, 빨대, 볼 부풀리기 등의 복식호 흡과 발성을 촉진시켜줄 수 있는 방법을 적용하여 실시하였으 며 복식호흡을 사용한 호흡 및 발성방법이 익숙해진 후 점차 소 거시키는 전이활동을 실시하였다. 
마지막으로 발화단계에서는 호흡, 발성 단계에서 수행한 발 성방법을 기본으로 음절, 단어, 문장 그리고 대화 수준에서 일 반화 활동이 될 수 있도록 훈련하였다. 성대에어로빅치료 프로 그램 각 훈련 단계는 표 2와 같다.

표 2. 성대에어로빅치료법 프로그램 절차

Table 2. Process of vocal aerobic treatment program

\begin{tabular}{|c|c|c|}
\hline Phase & Process & Criteria \\
\hline Consulting & $\begin{array}{l}\text { 1. Vocal hygeine } \\
\text { 2. Check for voice problem } \\
\text { 3. Check for home voice training }\end{array}$ & Score : 4 \\
\hline Relaxation & $\begin{array}{l}\text { 1. Stretching of body } \\
\text { 2. Laryngeal massage }\end{array}$ & Score : 4 \\
\hline Breathing & $\begin{array}{l}\text { 1. Abdominal breathing } \\
\text { 1) Supine position } \\
\text { 2) Sitting position } \\
\text { 3) Upright position } \\
\text { 2. Expiration exercise with straw \& } \\
\text { water } \\
\text { 3. Breathing accent exercise } \\
\text { 1) Consonant /S/ } \\
\text { 2) Straw and water }\end{array}$ & $\begin{array}{r}\text { Score : } 4 \\
20 \mathrm{sec}\end{array}$ \\
\hline Phonation & $\begin{array}{l}\text { 1. Maximum sustained phonation } \\
\text { exercise } \\
\text { 1) With straw and water } \\
\text { 2) With staw } \\
\text { 3) With vowel } \\
\text { 2. Pitch exercise } \\
\text { 1) Low pitch } \rightarrow \text { high pitch } \\
\text { 2) High pitch } \rightarrow \text { low pitch } \\
\text { 3) Low pitch } \rightarrow \text { high pitch } \rightarrow \text { low pitch } \\
\text { 3. Loudness exercise } \\
\text { 1) With consonat /z/ } \\
\text { 2) With straw } \\
\text { 4. Pitch \& loudness exercise } \\
\text { 1) With singing }\end{array}$ & $\begin{array}{r}\text { Score : } 4 \\
20 \mathrm{sec}\end{array}$ \\
\hline Speaking & $\begin{array}{l}\text { 1. Speaking exercise with word } \\
\text { 1) Syllable units } \\
\text { 2) Spacing units } \\
\text { 3) One word units } \\
\text { 2. Speaking exercise with sentence } \\
\text { 1) Spacing units } \\
\text { 2) One sentence units } \\
\text { 3. Speaking exercise with paragraph } \\
\text { 1) Speech rate } \\
\text { 2) Pause } \\
\text { 3) Intonation }\end{array}$ & Score : 4 \\
\hline
\end{tabular}

\section{4. 분석방법}

통계처리는 SPSS 21.0 for Window를 사용하였으며 치료 전 후 성대에어로빅치료법의 음성개선 효과를 알아보고자 윌콕슨 부호순위 검정(Wilcoxon Signed-Rank test)을 통해 분석하였다.

\section{3. 연구 결과}

3.1. 음향학적 평가 결과

\subsubsection{MDVP}

음성치료 전·후 $\mathrm{MDVP}$ 를 실시한 결과, 남성과 여성 모두 치
료 후 Jitter, Shimmer, NHR의 수치가 통계적으로 유의하게 감소 하였다 $\left({ }^{*} p<.05,{ }^{* *} p<.01,{ }^{* * *} p<.001\right)$. 음도의 경우 여성 환자는 $\mathrm{Fo}$ 수치가 유의하게 증가하였으나( $\left.{ }^{*} p<.05\right)$ 남성 환자는 통계적으 로 유의한 차이가 나타나지 않았다.

이러한 결과는 성대에어로빅치료 프로그램이 음질과 관련된 매개변수인 Jitter, Shimmer, NHR의 개선에 효과적이며, 환자의 음질이 개선되었다고 할 수 있다. MDVP 각 매개변수 변화는 표 3 과 같았다.

\section{표 3. 사전·사후 $\mathrm{MDVP}$ 결과}

Table 3. Reasult of acoustic evaluation (MDVP) pre test and post test

\begin{tabular}{|c|c|c|c|c|c|}
\hline \multicolumn{2}{|c|}{ Parameter } & Pre-test & Post-test & $t$-value & $p$-value \\
\hline \multirow{2}{*}{ Fo } & Male & $\begin{array}{l}158.119 \\
(43.615) \\
\end{array}$ & $\begin{array}{r}148.126 \\
(36.838) \\
\end{array}$ & -.524 & 0.600 \\
\hline & Female & $\begin{array}{l}205.324 \\
(24.137) \\
\end{array}$ & $\begin{array}{l}224.303 \\
(11.068) \\
\end{array}$ & -2.028 & $.043^{*}$ \\
\hline \multicolumn{2}{|c|}{ Jitter } & $2.020(1.261)$ & $0.547(.238)$ & -3.547 & $.000^{* * *}$ \\
\hline \multicolumn{2}{|c|}{ Shimmer } & $7.051(4.378)$ & $3.177(.959)$ & -3.621 & $.000^{* * * *}$ \\
\hline \multicolumn{2}{|c|}{ NHR } & $0.165(.077)$ & $0.125(.012)$ & -2.396 & $.017^{*}$ \\
\hline
\end{tabular}

\subsubsection{VRP}

음성치료 전·후 음성장애환자의 음역 변화를 알아보고자 $\mathrm{VRP}$ 를 실시한 결과, 남성 환자는 치료 후 주파수 범위 $(\mathrm{Hz})$, 주 파수 범위(Semitones)에서 통계적으로 유의미하게 증가하였으 며 $\left(^{* *} p<.01\right)$, 여성 환자에서도 치료 후 주파수 범위 $(\mathrm{Hz})$, 주파수 범위(Semitones)가 통계적으로 유의미하게 증가하였다 $\left.{ }^{*} p<.05\right)$. 반면 강도범위(energy range)에서는 통계적으로 유의한 차이가 나 타나지 않았다.

음성치료 후 환자의 주파수 범위와 관련된 음역의 향상이 나 타났으며 성대에어로빅치료 프로그램은 음역 개선에 효과적인 것으로 나타났다. VRP 각 매개변수 변화는 표 4 와 같았다.

표 4. 사전·사후 VRP 결과(남성)

Table 4. Reasult of acoustic evaluation (VRP) pre test and post test (male)

\begin{tabular}{c|c|c|c|c|c}
\hline \multicolumn{2}{c|}{ Parameter } & Pre-test & Post-test & $t$-value & $p$-value \\
\hline \multirow{2}{*}{$\begin{array}{c}\text { Fo } \\
\text { range }\end{array}$} & $\mathrm{Hz}$ & $\begin{array}{c}150.762 \\
(40.791)\end{array}$ & $\begin{array}{c}260.455 \\
(749.777)\end{array}$ & -3.040 & $.002^{* *}$ \\
\cline { 2 - 6 } & Semitone & $\begin{array}{c}13.846 \\
(3.312)\end{array}$ & $\begin{array}{c}20.461 \\
(5.882)\end{array}$ & -3.192 & $.001^{* *}$ \\
\hline $\begin{array}{c}\text { Energy } \\
\text { range }\end{array}$ & $\mathrm{dB}$ & $\begin{array}{c}28.000 \\
(12.851)\end{array}$ & $\begin{array}{c}29.4615 \\
(11.273)\end{array}$ & -.350 & .726 \\
$\begin{array}{l}* * * \\
p<.01 .\end{array}$
\end{tabular}

VRP, voice range profile. 
표 5. 사전·사후 VRP 결과(여성)

Table 5. Reasult of acoustic evaluation (VRP) pre test and post test (female)

\begin{tabular}{c|c|c|c|c|c}
\hline \multicolumn{2}{c|}{ Parameter } & Pre-test & Post-test & $t$-value & $p$-value \\
\hline \multirow{2}{*}{$\begin{array}{c}\text { Fo } \\
\text { range }\end{array}$} & $\mathrm{Hz}$ & $\begin{array}{c}268.120 \\
(103.23)\end{array}$ & $\begin{array}{c}369.083 \\
(186.547)\end{array}$ & -2.197 & $.043^{*}$ \\
\cline { 2 - 6 } & Semitone & $\begin{array}{c}16.571 \\
(5.912)\end{array}$ & $\begin{array}{c}19.857 \\
(7.267)\end{array}$ & -1.997 & $.046^{*}$ \\
\hline $\begin{array}{c}\text { Energy } \\
\text { range }\end{array}$ & $\mathrm{dB}$ & $\begin{array}{c}22.857 \\
(9.924)\end{array}$ & $\begin{array}{c}24.286 \\
(8.616)\end{array}$ & -.507 & .612 \\
\hline
\end{tabular}

${ }^{*} p<.05$

VRP, voice range profile.

\section{2. 공기역학적 평가 결과}

\subsubsection{PAS}

음성치료 전·후 발성과 관련된 호흡기능의 변화를 알아보고 자 $\mathrm{PAS}$ 를 실시한 결과, 치료 후 폐활량 $(\mathrm{FVC})$, 최대연장발성시 간(PHOT)의 수치가 통계적으로 유의하게 증가하였다( ${ }^{* *} p<.01$, $\left.{ }^{* * *} p<.001\right)$. 반면 평균호기류율(MEAF), 평균성문하압(MPAP), 음 성효율성(AEFF)의 수치는 통계적으로 유의한 차이가 나타나지 않았다.

이처럼 성대에어로빅치료 프로그램은 발성과 관련된 호흡기 능 중 $\mathrm{FVC}$ 와 PHOT 향상에 효과적인 것으로 나타났다. PAS 각 매개변수 변화는 표 6과 같았다.

표 6. 사전·사후 PAS 결과

Table 6. Reasult of aerodynamic evaluation (PAS) pre-test and post-test

\begin{tabular}{c|c|c|c|c}
\hline Parameter & Pre-test & Post-test & $t$-value & $p$-value \\
\hline FVC & $\begin{array}{c}2.873 \\
(.905)\end{array}$ & $\begin{array}{c}3.682 \\
(.746)\end{array}$ & -3.379 & $.001^{* *}$ \\
\hline PHOT & $\begin{array}{c}11.762 \\
(5.584)\end{array}$ & $\begin{array}{c}17.837 \\
(5.584)\end{array}$ & -3.582 & $.000^{* * *}$ \\
\hline \multirow{2}{*}{ MEAF } & $\begin{array}{c}0.135 \\
(.086)\end{array}$ & $\begin{array}{c}0.127 \\
(.086)\end{array}$ & -.101 & .920 \\
\hline \multirow{2}{*}{ MPAP } & $\begin{array}{c}11.387 \\
(3.319)\end{array}$ & $\begin{array}{c}11.115 \\
(3.319)\end{array}$ & -.336 & .737 \\
\hline \multirow{2}{*}{ AEFF } & $\begin{array}{c}405.740 \\
(818.425)\end{array}$ & $\begin{array}{c}651.193 \\
(1,385.693)\end{array}$ & -1.867 & .062 \\
\hline${ }^{* * *} p<.01,{ }^{* * *}$ & $p<.001$. & &
\end{tabular}

FVC, expiratory volume; PHOT, phonation time; MEAF, mean expiratory airflow; MPAP, mean peak air pressure; AEFF, aerodynamic efficiency.

\section{3. 후두스트로보스코피 검사 결과}

\subsection{1. 후두스트로보스코피}

음성치료 전·후 성대질환 및 성대 움직임의 변화를 알아보고 자 후두스트로보스코피를 실시한 결과는 다음과 같았다. 환, 기 능적 음성장애, 인후두역류질환 대상군에서는 치료 전에 비하여 치료 후 진폭, 점막파동, 양측성대의 대칭성, 양측성대의 규칙성 에서 정상인에 해당되는 소견을 보였다. 반면 연축성 발성장애, 성대마비, 성대폐쇄부전, 노인성 음성장애 대상군에서는 치료 후 치료 전에 비하여 저명한 호전 소견을 보였으나 정상 범주에 속하지는 않았다. 후두스트로보스코피 예는 그림 1과 같았다.

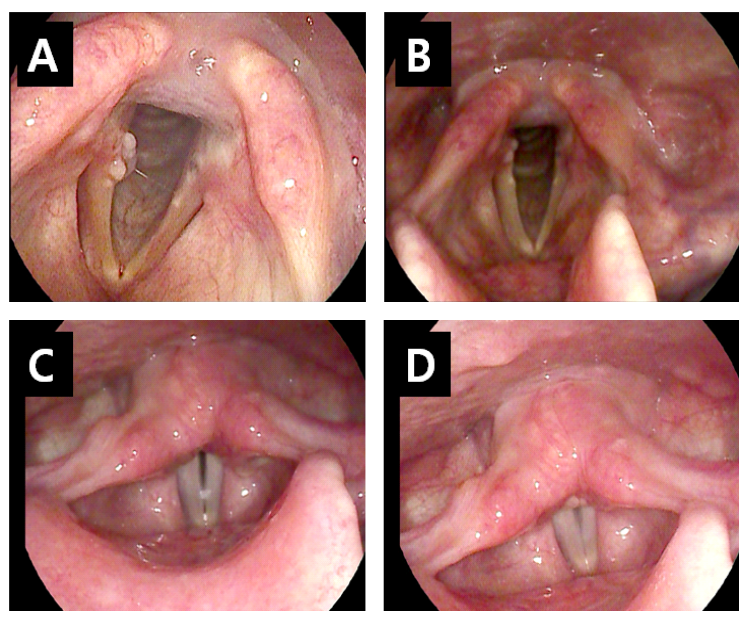

그림 1. 치료 전·후 후두스트로보스코피 예 Figure 1. Example of videostroboscopy finding pretherapy and posttherapy Contact granuloma (A, pretherapy; B, posttherapy), Incomplete glottal closure (C, pretherapy; D, posttherapy)

\section{4. 논의 및 결론}

본 연구는 총체적 음성치료법을 기반으로 둔 성대에어로빅 치료법이 음성장애환자의 음성개선에 미치는 효과에 대해 알 아보고자 하였다. 연구결과를 종합해 보자면 다음과 같다.

첫째, 음성장애 환자의 음도 및 음질 개선을 알아보고자 $\mathrm{MDVP}$ 를 실시한 결과 음질과 관련된 매개변수인 Jitter, Shimmer, $\mathrm{NHR}$ 에서 통계적으로 유의한 감소가 나타났으며 음성장애환자 의 음질의 개선을 확인할 수 있었다. Fo에서 여성 환자의 경우 성대 병변 호전으로 음도가 유의하게 증가하였으나 남성 환자 의 경우 $\mathrm{Fo}$ 에서는 유의한 차이가 나타나지 않았다. 이러한 결과 는 성대결절 환자에게 복식호흡 및 self voice feedback 프로그램 을 적용하여 프로그램의 효과성을 검증한 결과 $\mathrm{Fo}$ 에서는 통계 적으로 유의미한 차이가 없었다는 연구와 근긴장성 발성장애, 성대결절, 성대용종 환자를 대상으로 후두마사지와 반폐쇄성 도훈련을 실시한 결과 $\mathrm{Fo}$ 에서는 유의미한 변화가 나타나지 않 았다는 연구 결과와는 상이한 결과가 나타났다(Kim et al., 2017; Kwon et al., 2006). 본 연구에서는 vocal aerobic treatment (VAT) 의 효과를 다양한 집단의 환자에게 적용하여 실시한 연구로 향 후 연구에서는 동일 집단을 대상으로 실시하여 $\mathrm{Fo}$ 의 수치 변화 를 알아볼 필요가 있을 것이다.

둘째, 음역의 변화를 알아보고자 VRP 검사를 실시한 결과 주파수 범위 $(\mathrm{Hz})$ 와 반음의 개수(Semitone)에서 유의미한 차이 가 있었다. 그러나 강도범위(Energy range)에서는 유의한 차이 가 나타나지 않았다. 선행연구와 비교해 보면 성대결절 여성환 자에게 성대기능훈련을 실시한 8주간 실시한 결과, VRP 검사에 서 주파수 범위 $(\mathrm{hz})$ 가 통계적으로 유의미한 증가가 나타났다고 하였다(Lim et al., 2009). Kim(2015)의 연구에서는 노인 음성장 애환자를 대상으로 흡기발성기법을 사용한 음성치료 효과를 알아본 결과, 치료 후 주파수범위 $(\mathrm{hz})$ 가 증가하였으며 통계적으 로 유의하였다. 반면 강도범위(Energy range)는 증가하였으나 
통계적으로 유의미하지 않았다고 하였다. 또한 Yoo \& Lee(2018) 에서 성악가를 대상으로 성대에어로빅치료법의 음성 개선 효 과를 알아본 결과 치료 후 주파수 범위 $(\mathrm{Hz})$ 와 반음의 개수 (Semitone)가 증가하였다고 보고하였다. 이러한 결과는 본 연구 에서 결과와 일치하며 성대에어로빅치료 프로그램이 음성장애 환자의 음역을 개선시키는 데 효과적이라고 할 수 있다. 이러한 음역의 개선은 성대에어로빅치료 프로그램 내에 음도훈련을 통해 환자가 발성방법을 지속적으로 훈련함으로써 음역이 개 선되었다고 할 수 있다.

셋째, 발성과 관련된 호흡기능의 변화를 알아보고자 PAS 검 사를 실시하였다. 연구 결과 치료 후 폐활량(FVC), 최대연장발 성시간(PHOT)이 증가하였으며 이는 통계적으로 유의하였다. 이러한 결과는 선행연구에서 음성장애 환자에게 액센트 치료 법(Kwon et al., 2001), 성대기능훈련을 실시한 연구(Lim et al., 2016)와 성대용종, 수술 후 음성치료 환자, 만성후두염 환자에 게 음성치료를 실시한 연구에서 치료 후 최대연장발성시간이 유의하게 증가한 결과와 일치한다(Lu et al., 2018). 또한 Kang \& Yoo(2019)의 연구에서도 호흡훈련기를 사용한 성대에어로빅치 료 프로그램을 실시한 결과 폐활량 $(\mathrm{FVC})$, 최대연장발성시간 (PHOT)이 증가하였다고 보고하였다. 이처럼 성대에어로빅치 료 프로그램은 음성장애 환자의 발성과 관련된 호흡기능의 중 폐활량(FVC)과 최대연장발성시간(PHOT)에서 음성 개선이 나 타났다는 것을 확인할 수 있었다. 성대에어로빅 치료 프로그램 의 호흡과 발성 단계별 준거는 15-20초 이상 호기 또는 발성을 유지하는 것으로 이러한 훈련을 통해 폐활량 $(\mathrm{FVC})$ 과 최대연장 발성시간(PHOT)의 향상이 나타났다고 할 수 있다.

넷째, 성대질환 및 성대 움직임 변화를 알아보고자 후두스트 로보스코피를 실시하였다. 연구 결과 양성성대점막질환, 기능 적 음성장애, 인후두역류질환에서는 진폭, 점막파동, 양측 성대 의 대칭성, 양측 성대의 규칙성에서 정상범주에 속하였다. 또한 치료 후 육아종의 크기 감소하거나 성대 접촉양상의 향상이 나 타났으며 성문틈(glottal gap)이 감소한 소견을 보였다. 기타 대상 군에서는 정상범주에 속하지 않았으나 치료 후 저명한 호전 소 견을 보였다. $\operatorname{Kim}(2015)$ 의 연구에서는 후두보정기법이 노인성 음성장애 환자의 성대 소견에서 유의미하게 호전되었다는 결과 가 나타났으나 본 연구 결과에서는 선행 연구와 상이한 결과가 나타났다. 이는 본 연구에서 기타 대상군(성대마비, 성대폐쇄부 전, 노인성 음성장애, 연축성 발성장애)의 경우 대상군의 수가 적어 이를 일반화하는 데 한계가 있었다. 또한 각 질환의 이환기 간, 처음 내원 시 성대 운동 상태 등에 따라 치료 전·후 후두스트로 보스코피 결과 판독에 제한이 있기 때문이라고 판단된다.

이러한 결과를 종합해 보면 성대에어로빅치료 프로그램은 음성장애 환자의 음질과 음역 개선, 폐활량, 최대연장발성시간 과 같은 발성과 관련된 호흡기능 향상에 효과적인 것으로 확인 할 수 있었다. 또한 양성성대점막질환, 기능적 음성장애, 인후 두역류질환에서는 성대 움직임에서 정상범주에 해당하여 성대 움직임 변화에서도 긍정적인 영향을 끼치는 것으로 나타났다. 본 연구의 한계점과 향후 연구를 위한 제언은 다음과 같다.
첫째, 본 연구에서는 음성장애 집단별 수가 균일하지 않아 집 단 간 음성치료의 효과를 비교하는 데 한계가 있었다. 따라서 향후 연구에서는 동일 후두 질환에 따른 성대에어로빅치료 프 로그램의 효과를 알아볼 필요가 있다.

둘째, 본 연구에서는 음향학적 검사에서는 Fo, Jitter, Shimmer, $\mathrm{NHR}$, 공기역학적 검사에서 $\mathrm{FVC}, \mathrm{PHOT}, \mathrm{MEAF}, \mathrm{MPAP}, \mathrm{AEFF}$ 등 가장 대표적인 매개변수의 변화에 대해 분석하였는 데 향후 연구에서는 대표적인 변수뿐만 아니라 다양한 매개변수를 함 께 분석하여 음성 개선 정도를 확인하는 데 민감한 변수에 대해 분석할 필요가 있다고 생각한다.

셋째, 본 연구에서는 객관적 음성검사를 통해 음성장애 환자 의 음성 개선 정도를 알아보았다. 향후 연구에서는 객관적인 음 성 검사뿐만 아니라 청지각적인 평가, 음성장애지수 등 주관적 인 평가를 실시하여 주관적인 음성 변화에 대해 알아볼 필요가 있다고 생각한다.

\section{References}

Boone, D. R., McFarlane, S. C., Von Berg, S. L., \& Zraick, R. I. (2014). The voice and voice therapy (9th ed.). Boston: Pearon.

Kang, H. N., \& Yoo, J. Y. (2019). A case study of the effects of respiration trainers on vocal aerobic treatment program. Communication Sciences \& Disorders, 24(1), 244-260.

Kapsner-Smith, M. R., Hunter, E. J., Kirkham, K., Cox, K., \& Titze, I. R. (2015). A randomized controlled trial of two semioccluded vocal tract voice therapy protocols. Journal of Speech, Language, and Hearing Research, 58(3), 535-549.

Kim, J. S., Lee, D. W., Choi, C. H., \& Choi, S. H. (2017). Effects of laryngeal massage and semi-occluded vocal tract exercises for patients with hyperfunctional dysphonia. Communication Sciences \& Disorders, 22(4), 806-817.

Kim, S. T. (2015). Effects of SKLCT ${ }^{\circledR}$ for voice improvement in patients with presbyphonia. Phonetics and Speech Sciences, 7(3), 183-191.

Kwon, S. B., Kim, Y. J., Jo, C. W., Jeon, G. R., Lee, B. J., \& Wang, S. G. (2001). The effect of accent method in treating vocal nodule patients. Speech Sciences, 8(4), 87-98.

Kwon, S. B., Wang, S. G., Yang, B. G., \& Jeon, G. R. (2006). Effects of abdominal respiration and self voice feedback therapy on the voice improvement of patients with vocal nodules. Speech Sciences, 13(3), 133-153.

Lee, C. Y., An, S. Y., Chang, H., \& Son, H. Y. (2016). The effect of voice therapy in unilateral vocal fold paralysis. Journal of The Korean Society of Laryngology, Phoniatrics and Logopedics, 27(1), 45-50.

Lim, H. J., Choi, S. H., Kim, J. K., \& Choi, C. H. (2016). Effects of Lax Vox voice therapy in a patient with spasmodic dysphonia: A case report. Phonetics and Speech Sciences, 8(2), 57-63. 
Lim, H. J., Kim, J. K., Kwon, D. H., \& Park, J. Y. (2009). The effect of vocal function exercise on voice improvement in patients with vocal nodules, Phonetics and Speech Sciences, 1(2), 37-42.

Lu, D., Chen, F., Yang, H., Yu, R., Zhou, Q., Zhang, X., Zou J., ... Liu J. (2018). Changes after voice therapy in acoustic voice analysis of Chinese patients with voice disorders. Journal of Voice, 32(3), 386.e1-386.e9.

Nasser Kotby, M. (1995). The accent method of voice therapy (Vol. 1). San Diego, CA: Singular.

Ramig, L. O., Countryman, S., Thompson, L. L., \& Horii, Y. (1995). Comparison of two forms of intensive speech treatment for Parkinson disease. Journal of Speech, Language, and Hearing Research, 38(6), 1232-1251.

Stemple, J. C., Lee, L., D'Amico, B., \& Pickup, B. (1994). Efficacy of vocal function exercises as a method of improving voice production. Journal of Voice, 8(3), 271-278.

Verdolini Abbott, K. (2014) Lessac-Madsen resonant voice therapy in the treatment of secondary MTD. In J. C. Stemple (Ed.). Voice therapy: Clinical studies. San Diego, CA: Singular. Yoo, J. Y., \& Lee, H. N. (2018). A case study on vocal aerobic treatment voice therapy development and application for classical singers, Journal of Rehabilitation Research, 22(1), 157-168.

\section{- 박준희(Jun Hee Park)}

조선대학교병원 이비인후과 교수

광주광역시 동구 필문대로 365

Tel: 062-220-3200

Email: entjh28@hanmail.net

관심분야: 갑상선암, 음성(목소리)질환, 후두암, 편도암, 설

(혀)암, 침샘질환, 소아편도(PITA)

\section{- 유재연 (Jae Yeon Yoo)}

호남대학교 언어치료학과 교수

광주광역시 광산구 호남대길 100

Tel: 062-940-5546

Email: slpyoo@hanmail.net

관심분야: 직업적 음성, 음성치료, 스피치 애플리케이션 개발

- 이하나 (Ha Na Lee) 교신저자

조선대학교병원 이비인후과 언어재활사

광주광역시 동구 필문대로 365

Tel: 062-220-3200

Email: hhln34@gmail.com

관심분야: 음성장애, 음성치료, 애플리케이션기반 언어치료

프로그램 개발 


\title{
성대에어로빅치료법이 음성장애환자의 음성개선에 미치는 효과*
}

\author{
박 준 희 ${ }^{1} \cdot$ 유 재 연 ${ }^{2} \cdot$ 이하 나 ${ }^{3}$ \\ ${ }^{1}$ 조선대학교 의과대학 이비인후과학교실, ${ }^{2}$ 호남대학교 언어치료학과, ${ }^{3}$ 조선대학교병 원 이비인후과
}

\begin{abstract}
국문초록
본 연구는 성대에어로빅치료법(vocal aerobic treatment, VAT)이 음성장애 환자의 음성 개선에 미치는 효과에 대해 알아보았다. 연구대상은 후두스트로보스코피, 음성검사 상 음성장애로 진단된 20명(남 13명, 여 7명)이었다. 음향 학적 평가는 CSL(computerized speech lab)의 MDVP(Multi-Dimensional Voice Program)와 VRP(Voice Range Profile)를 통해 평가하였다. 공기역학적 평가는 PAS(Phonatory Aerodynamic System)를 통해 평가하였다. MDVP를 통해 치료 전·후 기본주파수(Fo), 주파수변동률(Jitter), 진폭변동률(Shimmer), 소음대배음비(NHR)의 변화를 측정하였고, VRP 에서는 치료 전·후 주파수 범위(Fo range), 강도범위(Energy range)를 측정하였다. PAS에서는 치료 전·후 폐활량 (FVC), 최대연장발성시간(PHOT), 평균호기류율(MEAF), 성문하압(MPAP), 음성효율성(AEFF)의 변화를 알아보았 다. 후두스트로보스코피에서는 치료 전·후 양측 성대의 규칙성, 대칭성, 점막파동, 진폭 변화 소견을 알아보았다. 음성치료는 총체적 음성치료 접근법 중 하나인 VAT 프로그램을 환자별로 주 1회 실시하였다. 환자별 평균 치료 회 기는 6.5회였다. 연구결과, MDVP에서는 Jitter, Shimmer, NHR이 통계적으로 유의하게 감소하였다 $(p<.001, p<.01$, $p<.05)$. VRP 결과, 주파수 범위에서 $\mathrm{Hz}$ 와 Semitones이 치료 후 유의미하게 향상하였다( $p<.01, p<.05)$. PAS 결과, $\mathrm{FVC}$, PHOT에서 유의미한 향상이 나타났다 $(p<.01, p<.001)$. 후두스트로보스코피 결과 치료 후 기능적 음성장애, 인후두 역류질환, 양성성대점막질환군에서 성대소견이 정상범주에 해당하였다. 따라서 VAT 프로그램은 음성장애환자의 음향학적·공기역학적·후두스트로보스코피 측면에서의 음성 개선에 효과적인 것으로 나타났다. 차후 연구에서는 동일 집단의 음성장애 환자에게 VAT 적용 연구가 필요하다고 생각된다. 또한 객관적인 음성 개선뿐만 아니라 주 관적 음성 개선을 알아볼 필요가 있다. 나아가 직업적 음성사용자를 대상으로 VAT 효과에 대한 적용연구가 필요 가 있다.
\end{abstract}

핵심어: 성대에어로빅치료 프로그램, 음성치료, 음성장애

\section{참고문헌}

강하늘, 유재연 (2019). 호흡훈련기를 활용한 성대에어로빅치료 프로그램의 음성개선 효과 사례연구. 언어청각장애연구, 24(1), 244-260.

권순복, 김용주, 조철우, 전계곡, 이병주, 왕수건(2001). 성대결절 환자에서 액센트 치료법의 효과. 음성과학, 8(4), 87-98.

권순복, 왕수건, 양병곤, 전계곡 (2006). 복식호흡훈련과 self voice feedback 프로그램이 성대결절 환자의 음성개선에 미치는 효 과. 음성과학, 13(3), 133-154.

김성태 (2015). 후두보정기법이 노인성 음성장애 환자의 음성개 선에 미치는 효과. 말소리와 음성과학, 7(3), 183-191.

김지성, 이동욱, 최철희, 최성희 (2017). 후두마사지와 반폐쇄성 도훈련이 과기능적 음성장애 환자의 음성개선에 미치는 효과.
언어청각장애연구, 22(4), 806-817.

박영학, 이정학, 주영훈, 박성신, 방충일, 김민식, 조승호 (2005). 양성 성대 질환 환자의 후두 미세 수술전후 음성장애 지수 및 음성 분석의 유용성. 대한음성언어의학회지, 16(1), 23-27. 유재연, 이하나 (2018). 성악가를 위한 VAT 음성치료 개발 및 적 용 사례연구, 재활복지, 22(1), 157-168.

이창윤, 안수연, 장현, 손희영 (2016). 일측성 성대마비 환자의 음 성치료 효과. 대한후두음성언어의학회지, 27(1), 45-50.

임혜진, 김정규, 권도하, 박준영 (2009). 성대기능훈련이 성대결 절 환자의 음성개선에 미치는 효과. 말소리와 음성과학, $1(2)$, 37-42.

임혜진, 최성희, 김정규, 최철희 (2016). 연축성 발성장애 환자의 Lax Vox 음성치료 효과. 말소리와 음성과학, 8(2), 57-63.

* 이 논문은 2016학년도 조선대학교 연구비의 지원을 받아 연구되었음. 